

\section{Sumário}

Ordenamiento ambiental del terRitorio y participación CiUdadana en Argentina: aportes posibles DESDE EL DERECHO 2

María Valeria Berros

Matéria ambiental nos tribunais da Austrália e nova Zelândia ................................................... 17 Marcio Oliveira Portella

Conservação da BIODIVERSIDADE E POLÍtICAS PÚbLICAS PARA AS ÁREAS PROTEGIDAS NO BRASIL: DESAFIOS E

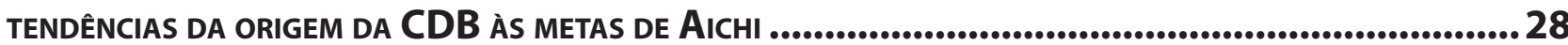

Ana Paula Leite Prates e Marta de Azevedo Irving

Dimensões linguísticas dA DESIGUALDADE No BrASIL: OS DIVERSOS NOMES LEGAIS DE UM MESMO FENÔMENo

Jefferson Carús Guedes

ECONOMIA, ÉTICA E TRIBUTAÇÃO: DOS FUNDAMENTOS DA DESIGUALDADE

Rafael Köche e Marciano Buffon

A REPARTIÇÃO de RENDAS ENTRE OS ENTES DA FEDERAÇÃO E SUA REPERCUSSÃo NA CARACTERIZAÇÃo DO FEDERALISMO BRASILEIRO: UMA INVESTIGAÇÃO ACERCA DO DESENVOLVIMENTO DO FEDERALISMO FISCAL-FINANCEIRO NO BRASIL.

Raquel Mousinho de Moura Fé

UMA AVALIAÇÃO DO ÍNDICE DE INCLUSÃO FINANCEIRA NOS ESTADOS DO NORDESTE BRASILEIRO

Diego Araujo Reis e Osvaldo Sousa Ventura

Fatores determinantes do Índice de Desenvolvimento Humano dos Municípios do Estado de São

PaUlo

Leandro Campi Prearo, Maria Clara Maraccini e Maria do Carmo Romeiro

As políticas públicas de acesso e difusão da cultura no Brasil e o caso do Programa Nacional de Apoio à Cultura. 157

Telma Rocha Lisowski

MoldANDO A "RESERVA do POSSível" NO TEMPO: A SUSTENTABILIDADE FISCAL COMO DIREITO DIFUSO FUNDAMENTAL. 171

Leonardo Romero Marino 
O PODER JUDICIÁRIO E A EFETIVAÇÃO DO DIREITO À SAÚDE

João Luis Nogueira Matias e Águeda Muniz

EDUCAÇÃo SUPERIOR NO BRASIL: OFERTA NA OMC, UMA REFLEXÃO DESMISTIFICADA, COM BASE EM DADOS ESTATÍSTICOS 208

Marcel Vitor Guerra

A GARANTIA DO DIREITO À EDUCAÇÃO DE CRIANÇAS E ADOLESCENTES NO CONTEXTO DAS POLÍTICAS PÚBLICAS BRASILEIRAS

André Viana Custódio e Rafael Bueno da Rosa Moreira

A POLÍCIA JUDICIÁRIA E O COMBATE À CRIMINALIDADE

Júlio Lopes Hott

Processo eleitoral e políticas Públicas: influÊnCias ReCíProcas.

Pablo Malheiros da Cunha Frota

SOCIEDADES PRIMITIVAS E DIREITO CONTEMPORÂNEO: DE QUE FORMA A JUSTIÇA TRIBAL PODE NOS AJUDAR A REPENSAR A NOSSA JUSTIÇA 303

Amanda Rodrigues e Tiago Themudo

DIREITO PRIVADO, JUSTIÇA DISTRIBUTIVA E O ARGUMENTO DA DUPLA DISTORÇÃO: UMA REVISÃO DA LITERATURA ...........318 Leandro Martins Zanitelli

DistorçõES NO CONTROLE CADASTRAL DAS ENTIDADES SINDICAIS E CONTRIBUIÇÃO SINDICAL Ricardo Bravo

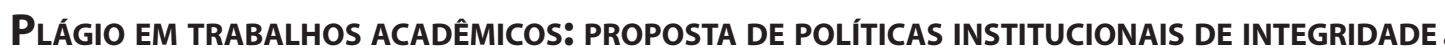
354 Maria Edelvacy Pinto Marinho e Marcelo Dias Varella 


\title{
Distorções no controle cadastral das entidades sindicais e contribuição sindical*
}

\author{
Discrepancies in base of registered labor \\ and employe unions and compulsory \\ contribution
}

Ricardo Bravo**

\section{Resumo}

Este texto objetiva a discussão sobre a qualidade dos dados de registros de entidades sindicais no Ministério de Trabalho e Emprego (MTE), como dados de contribuições trabalhistas dos trabalhadores dessas entidades e outros repasses. São elementos importantes para que se compreendam falhas na distribuição da contribuição sindical obrigatória, assim como evidenciar a existência de associações meramente formais que se aproveitam da compulsoriedade das contribuições. Para essa abordagem, analisou-se a base cadastral de entidades sindicais disponível no MTE com cerca de 17 mil associações e suas inter-relações. Com base nesses dados se constatam diversas discrepâncias tais como vigência de atos de cadastro e processos, falhas na informação sobre a pirâmide sindical e excesso de homonímia entre dirigentes sindicais. Tais circunstâncias influem na contribuição compulsória e ainda prejudicam o balanço entre liberdade e unicidade sindical, já que certas casos criam barreiras à constituição de sindicatos efetivamente representativos. Também analisaram-se dados sobre regularidade das entidades sindicais em relação à contribuição previdenciária e ao fundo de garantia, no qual se constatou que a maior parte das entidades encontra pendências - o que indica, no mínimo, desídia em relação aos seus trabalhadores. Os resultados sugerem falta de transparência e de controle sobre o cadastro, e tal abordagem representa inovação enquanto método potencial de avaliação de políticas públicas.

Palavras-chave: Cadastro sindical. Unicidade. Contribuição sindical.

* Recebido em 01/07/2014 Aprovado em 05/10/2014

\footnotetext{
** Possui graduação em Engenharia da Computação pelo Instituto de Tecnologia da Aeronáutica (ITA) e graduação em Direito pela Universidade de Brasília (UnB). É mestre em Engenharia Eletrônica e Computação pelo Instituto Tecnológico de Aeronáutica (2004). Atualmente é analista legislativo (Senado Federal) e mestrando em Direito e Políticas Públicas pelo Centro Universitário de Brasília - UniCEUB. E-mail: ricardobravo@uol.com.br
}

\section{Abstract}

This paper aims to discuss the quality of the data records of the Ministry of Labour and Employment (in portuguese Ministério do Trabalho e Emprego [MTE]), as data about labor contributions of employees of these entities and other monetary transfers. These elements are important in order to understand failures in the distribution of compulsory union dues, which can serve as evidence of the existence of formal associations built only to take advantage of obligatory contributions. In order to achieve those objectives, we analyze the base of registered labor and employer unions available at the MTE web site, which consists of about 17,000 associations and their 
interrelations. Based on these data, the paper shows many discrepancies such as validity of acts and registration processes, gaps in information about the union pyramid structure, and excessive homonymy between managers in different unions. These circumstances influence the compulsory contribution and influence the balance between freedom and unicity, since some cases create barriers to the creation of labor unions that effectively represents its members. The paper also analyzes data on regularity of labor union in relation to taxes such as Brazilians Employment Compensation Fund and social security contributions. Such data indicates that most associations held debts or irregularities, which indicates at least negligence in relation to its own employees, if not unlawful. The results suggest lack of transparency and control over the registration and influence to transfer, and such an approach represents an innovation related to indicators of public policy of compulsory transfers and taxes.

Keywords: Labor and trade unions registration. Labor unions unity. Labor union taxes.

\section{INTRODUÇÃo}

Um tema constante na pauta sobre a atuação sindical no cenário nacional é o déficit de representatividade e efetividade da representação sindical em relação aos trabalhadores, seus representados. Muito se questiona no modelo brasileiro a questão da unicidade, que é a imposição de exclusividade de representação para uma categoria econômica ou profissional em determinada área não menor que um município, sendo que a aferição desse preceito é feito no momento do cadastro da entidade sindical junto ao Ministério do Trabalho. Tal configuração cadastral repercute na forma de recolhimento de contribuição dos associados, mas principalmente naqueles que são somente membros de categoria profissional e mesmo assim recolhem contribuições compulsoriamente, o que leva a reflexos no conceito de liberdade sindical.

O registro do sindicato serve para dar segurança jurídica aos representados nas negociações coletivas, bem como se mostra adequado ao controle da unicidade sindical, mas, também, pode significar ingerência estatal no funcionamento dos sindicatos, uma vez que a concretização do conceito de unicidade sindical ocorre em normativos legais ou infralegais. Outrossim, pode gerar conflito se a associação que deveria representar determinada categoria em determinado local tem a representação legal, mas não a representatividade de fato. Considerando-se a rigidez da regra cronológica do registro, os vícios na classificação de categorias, mudanças sociais, a existência de contribuição compulsória para os membros das categorias independentemente de filiação e chega-se a uma situação limite em que o empregado não é representado, não pode escolher outro sindicato e ainda sua desfiliação exerce pouca influência sobre o cenário, pois não influencia nas verbas e nem na estrutura sindical. Nessa linha, uma questão que provoca debates calorosos é o recebimento compulsório de renda garantida pelos sindicatos, o que contribui para sua acomodação, com consequente pouca representatividade e cria distorções de grande parte da estrutura sindical. O recente reconhecimento das centrais sindicais, ao lado da destinação de polpudas verbas, reacendeu o debate sobre o controle e aplicação desses recursos, que não deixa ser uma espécie de verba pública.

Neste texto são elencados diversos dados que corroboram a ideia de que muitos sindicatos apenas buscam a representação formal, e recebimento de verbas, em detrimento de sua função constitucional de representação dos trabalhadores. Mesmo se utilizando apenas de dados públicos, se observam diversos indícios de ilegalidades e distorções na aplicação das verbas recebidas compulsoriamente ou via ações governamentais. A partir da coleta e análise de dados públicos sobre o cadastro sindical, contribuição sindical, dados de dirigentes sindicais, recolhimento de impostos e contribuições previdenciárias, pode-se evidenciar que a combinação desses fatores se traduz em oportunismo, abuso de direito para um número substancial de entidades sindicais, em detrimento daqueles que deveriam representar. De certa forma, busca-se questionar elementos que, conjugados, não representam a liberdade sindical ou seu sentido teleológico. Na mesma linha, questiona-se o papel do próprio cadastro e do Ministério do Trabalho e Emprego (MTE), seu gestor, 
no que tange as questões referentes a sindicatos. Não se almeja discorrer sobre todas as facetas da liberdade sindical e da efetividade da atuação sindical, mas são evidenciados indicadores em amostras de dados que corroboram a ideia de que existem profundas e inaceitáveis distorções no sistema sindical brasileiro, especialmente no que tange ao cadastro de sindicatos e de informações relacionadas.

A partir da massa de dados busca-se responder algumas perguntas sobre a qualidade do cadastro, as indicações de dirigentes sindicais, sobre participação efetiva de entidades sindicais em negociações coletivas, sobre quantidade de empregados em sindicatos, e pagamento de contribuições e recolhimentos compulsórios sobre estes e, de um modo geral, se as discrepâncias e distorções se coadunam com a liberdade sindical em si.

Na sequencia se destacam aspectos normativos e históricos da contribuição sindical e evolução do reconhecimento das entidades sindicais. Também se destaca a evolução do tratamento constitucional dado aos sindicatos, formas de representação, incluindo a unicidade sindical. Após esse esclarecimento normativo e conceitual, indicam-se algumas conclusões a partir de dados empíricos e, ao final, destacam-se conclusões sobre a situação apresentada.

\subsection{Breve histórico sobre reconhecimento dos sindicatos e contribuição compulsória}

O financiamento sindical tem sido palco de discussões que vão desde a interferência indevida do Estado nas entidades, questionamentos entre direito de associação, liberdade sindical e efetiva representatividade, algo que é evidenciado pelo histórico, evolução normativa e contradições que são apontadas na doutrina.

A história dos sindicatos no país é recente, inclusive, pela formação tardia de mercado de trabalho assalariado urbano. Conforme menciona Sandor Zapata, os primeiros sindicatos brasileiros surgiram em 1903, sendo que, em 1906, é fundada a Confederação Sindical Brasileira. ${ }^{1}$ Os sindicatos passaram a ter mais influência no país com o processo de urbanização e industrialização, após Primeira Guerra, período que foi marcado por acentuado intervencionismo estatal, algo que permitia ao Estado-maior controle das massas, seus anseios e limites de insurgência.

A primeira lei sindical da Era Vargas, Decreto no 19.770, de 1931, adotou como estratégia domesticar os sindicatos. A terceira, do Estado Novo, tratou de incluí-los na organização corporativa do Estado, criando o sindicalismo oficializado. Para sobrepô-lo a qualquer formação marginal que ressuscitasse os sindicatos de resistência, era preciso dar-lhes sustentação. Já que estava se distanciando da classe trabalhadora. A carta de 1937 antecipou a providência valendo-se de cópia de Carta de Lavoro como artifício de outorgar-lhe função delegada do Poder Público para impor uma contribuição compulsória a categorias nas quais se incluíam todos empregados, sindicalizados ou não. ${ }^{2}$

Exemplo da ingerência estatal, mesmo quando a representação sindical estava pautada em liberdade de associação é o Decreto no 24.694 de 1934, que permitia aos sindicatos reconhecidos o desconto nos salários dos sindicalizados de importâncias previstas em lei ${ }^{3}$. Já, no Estado Novo, e no contexto da Constituição de 1937, houve legislação admitia desconto imposto a todos da categoria ou profissão representada pelo sindicato, independentemente da efetiva associação:

1 ZAPATA, Sandor Ramiro Darn. A crise do paradigma sindical brasileiro: unicidade, contribuição obrigatória, sistema confederativo e poder normativo da justiça do trabalho. Revista de direito do trabalbo, São Paulo, v. 37, n. 142, p. 391, abr./jun. 2011

2 AROUCA, José Carlos. A liberdade sindical e a imposição da cobrança de contribuição. Repertório IOB de jurisprudência: trabalbista eprevidenciário, São Paulo, n. 2, p. 73-79, jan. 2012. p. 73.

Art 138 - A associação profissional ou sindical é livre. Somente, porém, o sindicato regularmente reconhecido pelo Estado tem o direito de representação legal dos que participarem da categoria de produção para que foi constituído, e de defender-lhes os direitos perante o Estado e as outras associações profissionais, estipular contratos coletivos de trabalho obrigatórios para todos os seus associados, impor-lhes contribuições e exercer em relação a eles funções delegadas de Poder Público.

3 REIS, Daniela Muradas. A imposição da contribuição sindical e o princípio da liberdade associativa: reflexões sobre o regime democrático e o financiamento sindical brasileiro. Repertório IOB de jurisprudência: trabalhista e previdenciário, São Paulo, n. 5, p. 158, mar. 2012. 
Assim o Decreto-Lei n 1.402 de 1939, entalhou novos contornos à atividade sindical no Brasil, atribuído pelo art. $3^{\circ}$, alínea $f$, entre outras prerrogativas sindicais, a de "impor contribuições a todos aqueles que participam de profissões ou categorias representadas". ${ }^{4}$

Deve-se destacar também o texto inicial da Consolidação das Leis do Trabalho (CLT), Decreto-lei 5.452 de $1^{\circ}$ de maio de 1943. O diploma indica elementos de distinção entre sindicato por categoria profissional ou de atividade em cada região (art. 540). O sistema de unicidade sindical do Decreto-Lei foi recepcionado e admitido pelas Constituições de 1946 e 1967, com poucas alterações.

A Constituição de 1946, considerada democrática, estabelecia no art. 159, que a lei ordinária poderia tratar da unidade ou pluralidade sindical, dependendo do critério que o legislador viesse adotar, tendo a Consolidação das Leis do Trabalho recepcionada pela Constituição, com seu sistema de unicidade.

A Constituição de 1967 estabelece no seu art. 159, ser livre a associação profissional ou sindical, modificando um pouco a situação que existia na Constituição de 1937, pois limitava a liberdade de o sindicato impor contribuições, para apenas arrecadar as contribuições de custeio da atividade dos órgãos sindicais e profissionais. ${ }^{5}$

A Constituição Federal de 1988 (CF/88) trouxe diversas inovações tais como as disposições do art. $8^{\circ}$ IV e $\mathrm{V}$ que definem o que pode ser caracterizado como liberdade sindical negativa, e contribuição que atendia a sindicatos e confederações e a autonomia dos sindicatos perante o Poder Público. Apesar de ter estabelecido tais garantias, a Carta Magna condicionou a liberdade à unicidade sindical em base territorial mínima como sendo a área de um município. A liberdade de associação constitucionalmente prevista no art. $8^{\circ}$ conjugada com a unicidade em princípio não gera espaço para a liberdade sindical negativa, ou de não associação:

Conclusivamente, a liberdade sindical, o teor do inciso V do art. $8^{\circ}$ da Constituição configura direito individual negativo de filiação, que não se confunde com a submissão à representação sindical e à regência pelos instrumentos normativos subsequentes. Não fosse assim o empregador poderia invocar a liberdade sindical para excluir-se da aplicação da convenção e o trabalhador também, ainda mais quando se tratasse de negociação in pejus que o obrigasse, por exemplo, a deixar seu trabalho extraordinário num banco de horas (CLT, art. 59, $\left.\$ 1^{\circ}\right) .^{6}$

A compulsoriedade da contribuição e o sentimento de garantia de fonte de renda ensejam acomodação da atividade sindical e diminuição de representatividade já motivou diversas discussões acerca de sua extinção ou retirada da compulsoriedade. Por exemplo, no início do governo militar o tema ganhou relevo com o presidente Marechal Castelo $\mathrm{Branco}^{7}$, que apresentou projeto de lei a esse respeito que acabou sendo arquivado. Na mesma linha, destacam-se mobilizações dos presidentes José Sarney e Fernando Collor:

A “Nova Democracia” começou com José Sarney, que num primeiro momento, já pensou em modernizar as relações de trabalho. O Projeto de Lei $n^{\circ} 164$, de 1987, cuidou da receita sindical, admitindo uma contribuição pela representação nas negociações coletivas, que obrigava também os não sindicalizados [...]. No triste período em que estivemos sobre o Governo de Fernando Collor de Mello, de igual modo seu Ministro do Trabalho, Antônio Rogério Magri, propôs a extinção da contribuição, chegando a encaminhar para o Congresso projeto de lei que não foi adiante por falta de empenho, especialmente do presidente, que, pouco depois, seria deposto. Mais tarde, sua Comissão de Notáveis construiu o

4 REIS, Daniela Muradas. A imposição da contribuição sindical e o princípio da liberdade associativa: reflexões sobre o regime democrático e o financiamento sindical brasileiro. Repertório IOB de jurisprudência: trabalhista e previdenciário, São Paulo, n. 5, p. 157, mar. 2012.

5 ZAPATA, Sandor Ramiro Darn. A crise do paradigma sindical brasileiro: unicidade, contribuição obrigatória, sistema confederativo e poder normativo da justiça do trabalho. Revista de direito do trabalho, São Paulo, v. 37, n. 142, p. 391, abr./jun. 2011.

6 AROUCA, José Carlos. A liberdade sindical e a imposição da cobrança de contribuição. Repertório IOB de jurisprudência: trabalhista e previdenciário, São Paulo, n. 2, p. 69, jan. 2012.

7 AROUCA, José Carlos. A liberdade sindical e a imposição da cobrança de contribuição. Repertório IOB de jurisprudência: trabalhista eprevidenciário, São Paulo, n. 2, p. 70, jan. 2012.

Projeto elaborado por seu Ministro do Trabalho, Arnaldo Lopes Süssekind

Art. 17. Fica extinto o imposto sindical, de forma decrescente, a partir de $1^{\circ}$ de janeiro de 1967 , cumprindo ao Ministro do Trabalho e Previdência Social designar comissão integrada por representantes do Governo e das entidades sindicais de grau superior, para realizar os necessários estudos e apresentar o respectivo plano, a ser aprovado e expedido por decreto do Poder Executivo. 
anteprojeto que o Deputado João Melão Neto, que ocupava a pasta do Trabalho, apresentou à Câmara dos Deputados (Projeto de Lei no 390, de 1995). ${ }^{8}$

No governo Fernando Henrique Cardoso, destaca-se a Proposta de Emenda à Constituição (PEC) 623 /1998 que visava alterar a redação do art. 8 da CF/88, deixando às assembleias-gerais a fixação do montante a ser descontado. Já no governo Lula, cita-se a tramitação da PEC 369/20059 que buscou realizar uma minirreforma sindical, que não se exauria com a retirada da compulsoriedade da contribuição.

No campo das incoerências legislativas não se pode deixar de mencionar o não atendimento de uma reivindicação histórica: a ratificação da Convenção OIT 87 de 1948. É importante salientar a contribuição compulsória não se adéqua ao modelo de liberdade sindical preconizado pela convenção:

A Convenção no 87 , da Organização Internacional do Trabalho, estipula que trabalhadores e as entidades patronais, sem distinção de qualquer espécie, têm o direito de constituírem organizações de sua escolha. Todavia, o Brasil não ratificou mencionada Convenção, de forma que o modelo sindical em nosso país não é de liberdade plena, mas parcial.

Ainda que não façam qualquer esforço ou reivindicação em nome de seus representados os sindicatos recebem elevadíssimos valores a título de contribuição sindical, já que se trata de contribuição obrigatória, o que facilita a posição acomodada de alguns sindicatos, já que não precisam conquistar seus representados para receber as contribuições. Daí a propensão à inércia. ${ }^{10}$

A despeito de toda polêmica, a solução do ordenamento jurídico atual consiste na manutenção da contribuição, com a ressalva de que persistirá enquanto não se discipline contribuição negocial $\left(\operatorname{art} .7^{\circ}\right.$ da Lei 11.648 de 31-Mar-2008 ${ }^{11}$ ). Deve-se pontuar que a existência do parágrafo em nada acrescenta ao ordenamento jurídico, pois a presunção de continuidade da norma é um dos princípios basilares do direito. A artimanha legislativa revela, por outro lado, a dificuldade em eliminar distorções corporativas. A mesma lei inova ao reconhecer as centrais sindicais, que representa um pleito antigo da categoria, uma vez que tais centrais consistem em estruturas de debate que vão além das tradicionais categorias, mas aumenta a distorção ao atribuir-lhes custeio com as verbas compulsórias e buscar evitar toda e qualquer forma de controle sobre o uso de uma verba que é pública. Na lei supracitada, houve o reconhecimento jurídico das Centrais Sindicais, que, se por um lado reconhece a importância de uma estrutura representativa, não vinculada ao conceito de categoria, por outro ampliou distorções na contribuição sindical, inclusive na possibilidade da fiscalização do destino desta verba pública ${ }^{12}$ :

8 AROUCA, José Carlos. A liberdade sindical e a imposição da cobrança de contribuição. Repertório IOB de jurisprudência: trabalhista e previdenciário, São Paulo, n. 2, p. 72, jan. 2012.

9 BRASIL. Câmara dos Deputados. PEC 369/200. Dá nova redação aos arts. 8, 11, 37 e 114 da Constituição. Disponível em: <http://www.camara.gov.br/proposicoesWeb/fichadetramitacao?idProposicao=277153>. Acesso em: 27 jul. 2012.

Art. $8^{\circ}$. É assegurada a liberdade sindical, observando o seguinte:

I - O Estado não poderá exigir autorização para fundação de entidade sindical, ressalvado o registro no órgão competente, vedadas ao Poder Público a interferência e a intervenção nas entidades sindicais;

II - O Estado atribuirá personalidade sindical às entidades que, na forma da lei, atenderem a requisitos de representatividade, de participação democrática dos representados e agregação que assegurem a compatibilidade de representação em todos os níveis da negociação coletiva;

III - Às entidades sindicais cabe a defesa dos direitos e interesses coletivos ou individuais no âmbito da representação, inclusive em questões judiciais e administrativas;

IV - A lei estabelecerá o limite da contribuição em favor das entidades sindicais que será custeada por todos os abrangidos pela negociação coletiva, cabendo à assembléia geral fixar seu percentual, cujo desconto, em se tratando de entidade sindical de trabalhadores, será efetivado em folha de pagamento;

VII - É obrigatória a participação das entidades sindicais na negociação coletiva;

Art. 11. É assegurada a representação dos trabalhadores nos locais de trabalho, na forma da lei.

10 ANDRADE, Alexsander Fernandes. Os desafios para a liberdade sindical plena. Jornal trabalhista Consulex, Brasília, v. 28 , n. 1385, p. 7, jul. 2011.

11 Art. $7^{\circ}$ Os arts. 578 a 610 da Consolidação das Leis do Trabalho - CLT, aprovada pelo Decreto-Lei no 5.452, de 1o de maio de 1943, vigorarão até que a lei venha a disciplinar a contribuição negocial, vinculada ao exercício efetivo da negociação coletiva e à aprovação em assembléia geral da categoria.

12 Art. $6^{\circ}$ Os sindicatos, as federações e as confederações das categorias econômicas ou profissionais ou das profissões liberais 
Foi renovada, não como medida provisória, mas como o Projeto de Lei no 1.999. Bem avaliado o texto, fácil de concluir que era ruim, como o propósito de desmontar as confederações que já tinham perdido importância e espaço, mas veio como queriam as centrais sindicais, com direito de receberem 10\% do total da contribuição sindical, mesmo tendo antes, as principais, CUT e Força Sindical, clamado por sua extinção. Só que para surpresa geral, até dos deputados governistas, A Câmara aprovou a emenda do Deputado Augusto de Carvalho (PPS-DF), que dando nova redação ao art. 582 da Consolidação das Leis do Trabalho, condicionava o desconto à expressa autorização dos empregados. Surpresa maior foi a emenda do Deputado Antônio Carlos Panunzio (PSDB-SP) que determinava a submissão da receita advinda da Contribuição ao Tribunal de Contas. [...] No dia 31 de março, o Presidente Luiz Inácio Lula da Silva promulgou a Lei $\mathrm{n}^{\circ} 11.648$, reconhecendo as centrais que tanto defendeu e manteve a contribuição sindical que tanto combateu. Mas vetou o art. $6^{\circ}$, que dispunha sobre a fiscalização de contas, acatando pedidos cruzados do capital e do trabalho. ${ }^{13}$

Deve-se notar que, de certa forma, pinça-se o argumento da liberdade sindical para afastar qualquer controle sobre os gastos de uma contribuição que se dissocia frontalmente da liberdade de associação. A possibilidade de algum controle, além do cadastro sindical, é estabelecida no diploma que também criou a contribuição sindical, a CLT ${ }^{14}$. Há que se distinguir entre controle ou ingerência estatal e um mínimo de transparência que interessa a sociedade e aos representados pelas entidades.

O histórico é importante para que se evidencie se as razões que justificam a estrutura sindical e contribuições continuam presentes, assim como para verificar a compatibilidade das regras impostas já há certo tempo com os atuais ditames constitucionais. Na sequencia é tratada a forma como as categorias são organizadas em sindicatos, aspecto relevante para entender sobre quem pode recair a cobrança em tela.

\subsection{Unicidade sindical, enquadramento e liberdade sindical}

Para que se evidencie distorções no sistema de contribuição compulsória e na representatividade sindical, é mister que se explicitem conceitos operacionais acerca de unidade sindical e da forma como empregados são enquadrados nas diversas categorias e seus efeitos na liberdade sindical no cenário nacional.

Acerca de liberdade e unicidade sindical, cita-se Davi Furtado Meirelles, para quem é contraditório que a liberdade sindical abarque a organização interna das entidades sindicais, mas não as relações externas: entre os sindicatos e entre estes e seus representados. ${ }^{15} \mathrm{O}$ autor destaca ainda que as quatro grandes contradições entre liberdade sindical e a forma de organização sindical brasileira são 1) unicidade sindical, 2) o sistema confederativo sindical e o agrupamento por categorias, 3) a contribuição sindical e 4) o poder normativo da Justiça do trabalho. Os três primeiros têm respaldo constitucional, o que não significa que a Carta exauriu a possibilidade hermenêutica destes conceitos nem que as leis anteriores tenham sido recepcionadas da mesma forma. A seguir são explicados aspectos dos três primeiros conceitos, destacando pontos de interesse.

e as centrais sindicais deverão prestar contas ao Tribunal de Contas da União sobre a aplicação dos recursos provenientes das contribuições de interesse das categorias profissionais ou econômicas, de que trata o art. 149 da Constituição Federal, e de outros recursos públicos que porventura venham a receber.

Razões do veto: "O art. $6^{\circ}$ viola o inciso I do art. $8^{\circ}$ da Constituição da República, porque estabelece a obrigatoriedade dos sindicatos, das federações, das confederações e das centrais sindicais prestarem contas ao Tribunal de Contas da União sobre a aplicação dos recursos provenientes da contribuição sindical. Isto porque a Constituição veda ao Poder Público a interferência e a intervenção na organização sindical, em face o princípio da autonomia sindical, o qual sustenta a garantia de autogestão às organizações associativas e sindicais."

13 AROUCA, José Carlos. A liberdade sindical e a imposição da cobrança de contribuição. Repertório IOB de jurisprudência: trabalhista e previdenciário, São Paulo, n. 2, p. 70-71, jan. 2012.

14 CLT art. $592[\ldots]$

$\int 2^{\circ}$ Os sindicatos poderão destacar, em seus orçamentos anuais, até 20\% (vinco por cento) dos recursos da contribuição sindical para o custeio das suas atividades administrativas, independentemente de autorização ministerial. (Incluído pela Lei $\mathrm{n}^{\circ} 6.386$, de $9.12 .1976)$

$\int 3^{\circ} \mathrm{O}$ uso da contribuição sindical prevista no $\int 2^{\circ}$ não poderá exceder do valor total das mensalidades sociais consignadas nos orçamentos dos sindicatos, salvo autorização expressa do Ministro do Trabalho. (Incluído pela Lei no 6.386, de 9.12.1976)

15 MEIRELLES, Davi Furtado. Liberdade sindical: o modelo ideal. Revista de direito do trabalbo, São Paulo, v. 36, n. 137, p. 45-75, jan./mar. 2010. 
A unicidade sindical por meio de base territorial mínima e enquadramento em categorias profissionais e econômicas são elementos importantes para a compreensão de distorções no sistema sindical brasileiro. O controle da unicidade sindical é de competência do Ministério do Trabalho e Emprego (MTE) ${ }^{16}$, que realiza o cadastro das entidades sindicais. Algo que pode parecer uma mera formalidade ou questão de aplicação de regras esbarra em dificuldades tais como determinação entre limite da liberdade sindical e do controle, na definição de categorias, na interpretação destas a partir da atividade econômica exercida pela empresa, o que é algo que despreza idiossincrasias dos empregados. O que se constata é que as regras de enquadramento (território e categoria) não representam categorias precisas, o que gera insegurança jurídica, assim como há dissenso jurisprudencial e doutrinário sobre como deveria ser a normatização do cadastramento.

O MTE expediu a Portaria no 186/2008 como escopo de regulamentar os procedimentos acerca do registro sindical, preservando-se a unicidade sindical.

Todavia, não obstante a exigência de registro do sindicato no MTE e a obrigatoriedade da observância de procedimentos da unicidade sindical, é certo que, na prática, verifica-se a coexistência de vários sindicatos em uma mesma base territorial, representando a mesma categoria.

O impasse foi criado em razão da vedação da ingerência do Estado sobre a criação dos sindicatos que acaba instituindo situação limítrofe entre o direito de associação e a necessidade de controle da unicidade sindical, que poderá ser entendida como cerceamento à liberdade. ${ }^{17}$

Para alguns o texto Constitucional retirou toda atribuição estatal em qualificar o que viria a ser o conceito de categoria profissional ou econômica.

Com a vinda do novo Texto Constitucional de 1988, alguns sustentam que as regras de enquadramento sindical capitulado pela CLT, artigos 575, 576 e 577, estão revogados, fato que torna muito dificultoso fazer o enquadramento sindical.Neste sentido temos: Os considerandos da Portaria 896 do Ministro de Estado do Trabalho de 14.2.1997, que dispões: “- considerando que a Constituição Federal proibiu a interferência e a intervenção do Estado na organização sindical, e atribuiu aos trabalhadores e empregadores interessados a competência para definir o âmbito da categoria e da respectiva base territorial (art. $8^{\circ}$, incisos I e II).; - considerando-se que em face deste preceito constitucional, cessou a competência do Ministério do Trabalho para reconhecer entidades sindicais e proceder ao respectivo enquadramento, razão pela qual foi extinta a Comissão de Enquadramento Sindical. ${ }^{18}$

Na prática, todavia, o MTE continua a controlar a unicidade com base nas definições de categorias a partir do significado do nome atribuído no registro, algo que gera distorções. A literalidade do registro por si só não muda, mas seu sentido pode ser ampliado ou principalmente restrito com o tempo, especialmente por conta da especialização de profissões. Nessa linha definições amplas como "sindicato dos servidores públicos de Lugar", "sindicato dos servidores municipais de Lugar", "sindicato dos empregados no comércio de Lugar", "sindicato dos empregados do comércio varejista de Lugar", "sindicato do comércio varejista de feirantes", etc., podem ser restritivos à entrada de nova associação. Por exemplo, servidores municipais envolveriam também os terceirizados, que eventualmente teriam interesses contraditórios. Na mesma linha, comércio e comércio varejista poderiam levar a uma disputa sobre a possibilidade da entrada de um ou de outros; já sindicato de comércio varejista de feirantes pode tanto ser sindicato de autônomos como sindicato patronal e poderia conflitar com sindicato dos comerciantes de Lugar. Deve-se ter em mente que a socie-

16 INSTRUÇÃO NORMATIVA MTE No 01, DE 27 DEAGOSTO DE 1991.

considerando que o egrégio Superior Tribunal de Justiça por jurisprudência predominante vem decidindo que não pode o Poder Público estabelecer condições ou restrições para a criação de associação sindical e que, na ausência de lei complementar, o registro competente é o das pessoas jurídicas (MS 189-DF, MS 362-DF e MS 435-DF, dentre outros); $\quad$ considerando, ainda, que o egrégio Superior Tribunal de Justiça fixou jurisprudência no sentido de que o depósito de atos constitutivos de associações sindicais, no Arquivo de Entidades Sindicais Brasileiras -AESB, deste Ministério, não tem caráter autorizativo de funcionamento, nem significa interferência vedada na Constituição, e que, havendo impugnação de terceiros interessados, deverão as partes dirimir a controvérsia em juízo (MS 362-DF, MS 448-DF, MS 457-DF, MS 458-DF, MS 474-DF e outros).

17 CASTRO, Ismênia E. Oliveira de; FARANI, Veruska. Dos conflitos legais decorrentes da coexistência de idênticos sindicatos de categoria. Repertório IOB de jurisprudência: trabalhista e previdenciário, São Paulo, n. 7, p. 215-211, abr. 2011.

18 MORALES, Cláudio Rodrigues. Enquadramento sindical após a Constituição de 1988. São Paulo: LTr, 2003. p. 25. 
dade, profissões e, como decorrência, a organização sindical não são elementos estáticos, o que justifica a iminente necessidade de atualização e ajustes, o que muitas vezes conflita com regras territoriais ou tabela de ocupações inadequada.

A mutabilidade na situação cadastral sindical em relação à criação envolve ao menos quatro situações: categoria não foi organizada em sindicato, por desmembramento da categoria, por desmembramento da base territorial, por fusão de base territorial ou categoria. Dessas se verifica que a maior parte dos conflitos surgem com relação ao desmembramento, pois em certo sentido perde-se verba da contribuição sindical compulsória, como também por ser difícil comprovar a especificidade da categoria.

A situação mais conflitante é o desmembramento em razão da categoria profissional mais específica, derivada da categoria originária geral, e ainda, se esta exige a criação de um sindicato específico não tem sido tarefa fácil, especialmente para as empresas na análise da adequação de sua atividade preponderante com os sindicatos da categoria. ${ }^{19}$

[...] o Judiciário tem sido receptivo à tese de desmembramento de categorias pelo critério territorial, desde que um dos entes (o preexistente ou o novo) mantenha ao menos a área de um Município [...] Essa possibilidade tem estimulado alguns sindicatos de base maior que u m município a constituírem u m novo ente sindical em cada u m dos municípios que compõem a base territorial original, com a finalidade única de garantir a unidade da categoria e evitar que "aventureiros" venham tentar d i v i d i 1 a no futuro. Assim, estão nascendo muitos "sindicatos de gaveta", cuja existência está apenas no papel, sem qualquer ação sindical concreta, colaborando para o crescente aumento no número de sindicatos registrados no Ministério do Trabalho e Emprego. ${ }^{20}$

Outra questão tormentosa é o enquadramento dos trabalhadores em função da atividade do empregador. É de duvidosa constitucionalidade e adequação à liberdade sindical a definição da categoria do empregado pela atividade econômica do empregador, já que esta pode não representar interesses dos trabalhadores. Exceção ao enquadramento por categoria é a previsão legal expressa para o enquadramento por categoria diferenciada, que são profissões com regulamentação legal específica, assim como regras para enquadramento para sindicatos de empresas e de servidores públicos.

Categoria diferenciada - a regra de é de que a categoria dominante definida pelo objetivo econômico explorado exerce a vis atracttiva. O $\$ 3^{\circ}$ do art. 511 da CLT há de ser interpretado com razoabilidade, pena de se criar impasse dentro da empresa, com a presença de inúmeros empregados, com especialidades diversas, ditos diferenciados, pertencentes a categorias diversas. ${ }^{21}$

Além da categoria preponderante e diferenciadas destacam-se enquadramento para sindicatos de empresas e de servidores públicos.

Estabilidade - Dirigente sindical - Categoria diferenciada - O empregado de categoria diferenciada eleito dirigente sindical só goza de estabilidade se exercer na empresa atividade pertinente à categoria profissional do sindicato para o qual foi eleito dirigente (Item no 145 da Orientação Jurisprudencial da SDI). Recurso de Revista desprovido. ${ }^{22}$

O cenário de dificuldade de verificação da representação pode ser identificado pelo número expressivo de decisões sobre enquadramento sindical. Mesmo orientações jurisprudenciais como a 9 da Seção de Dissídios coletivos, pela qual o dissídio coletivo é via imprópria para enquadramento e estabelecendo a competência para Justiça comum evidencia por outro ângulo que representação formal distingue-se de representatividade. Outra orientação jurisprudencial que pode ser destacada nessa seara é a Orientação Jurisprudencial

19 CASTRO, Ismênia E. Oliveira de; FARANI, Veruska. Dos conflitos legais decorrentes da coexistência de idênticos sindicatos de categoria. Repertório IOB de jurisprudência: trabalhista e previdenciário, São Paulo, n. 7, p. 213, abr. 2011.

20 MEIRELLES, Davi Furtado. Liberdade sindical: o modelo ideal. Revista de direito do trabalho, São Paulo, v. 36, n. 137, p. 53, jan./ mar. 2010.

21 BRASIL. Tribunal Regional do Trabalho (2. Região). Recurso Ordinário. RO n. 02980429850-SP, ac. N. $19990382053.5^{a}$ Turma. Relator: Juiz Francisco Antonio de Oliveira. São Paulo DOJ 27.7.1999.

22 BRASIL. Tribunal Superior do Trabalho. Reconhecedor de Remissões. RR 411496. 5a Turma. Relator: Min. Rider Nogueira de Brito. Brasília, 07 de fevereiro, 2001. 
(OJ) do TST n ${ }^{\circ}$ 55, da Seção I de Dissídios Individuais ${ }^{23}$, pois se evidencia que os acordos coletivos não são feitos, por vezes, com o envolvimento do sindicato que o representa determinado trabalhador. Destaca-se, a seguir, o comentário sobre algumas agruras derivadas do conflito representativo entre sindicatos com atribuições coincidentes ou próximas.

Esse cenário gera insegurança jurídica à empresa, por não ter condições legais de realizar o repasse da contribuições sindicais dos trabalhadores de maneira adequada, bem como aplicar uma convenção coletiva em detrimento de outra, sem o fantasma do passivo trabalhista (nos âmbitos individual e coletivo).

O passivo trabalhista, no caso da aplicação da convenção coletiva, se daria em razão da existência de diferentes beneficiários insculpidos nas normas coletivas dos sindicatos "irmãos". ${ }^{24}$

O descompasso entre o texto constitucional e diversas regras que existiam antes do texto constitucional, não necessariamente recepcionadas, é evidenciado em outra regra cuja aplicação é relevante neste trabalho. Trata-se do art. $10^{25}$ da Lei 4.725/1965, referendado pela OJ 37 da Seção de Dissídios Coletivos do TST. Basicamente exclui da liberdade sindical que os trabalhadores do sindicato tenham seu sindicato. É certo que tais representações poderiam colidir com um modelo piramidal do sindicalismo brasileiro, mas serviria para a fiscalização pelos trabalhadores da atuação dos sindicatos. No trabalho, o ponto é crucial, pois se demonstra que as entidades sindicais são, na maioria, descumpridoras contumazes de normas protetivas trabalhistas acerca de contribuições previdenciárias e do Fundo de Garantia do tempo de Serviço (FGTS).

Além de definir, por meio de enquadramento, em que sindicato um trabalhador pode vir a se filiar, outro ponto de destaque é que as entidades sindicais em si podem se associar, criando o que se denomina pirâmide sindical. Sindicatos podem se associar, desde que haja identidade, similaridade ou conexão entre as profissões (CLT, art. 533) em número não menor que 5 para formar federações, em regra estaduais, mas podendo ser interestadual ou nacional. Já as federações podem ser reunir em número de pelo menos três para formar confederações. É possível que um sindicato não se filie a numa federação, assim como é possível a existência de mais de uma federação para dada atividade ou profissão ${ }^{26}$, mas cada sindicato só pode se filiar a uma federação, sendo que nenhuma pode ter menos de cinco sindicatos. De qualquer forma, tal estrutura piramidal é relevante porque em função das filiações, parcelas das contribuições obrigatórias são destinadas às federações e confederações. Destaca-se que as centrais sindicais estão ao lado desta estrutura, e desde o reconhecimento em 2008 recebem 10\% do total arrecadado pelas contribuições sindicais.

Estabelecidas as regras gerais de enquadramento e estrutura destacam-se alguns elementos da contribuição sindical. Trata-se de mecanismo de natureza tributária, parafiscal (ou seja, cuja arrecadação não é voltado para o Estado) que é um dos principais meios de financiamento das entidades e vincula a contribuição com-

23 "NORMA COLETIVA. CATEGORIA DIFERENCIADA. ABRANGÊNCIA. Empregado integrante de categoria profissional diferenciada não tem o direito de haver de seu empregador vantagens previstas em instrumento coletivo no qual a empresa não foi representada por órgão de classe de sua categoria."

24 CASTRO, Ismênia E. Oliveira de; FARANI, Veruska. Dos conflitos legais decorrentes da coexistência de idênticos sindicatos de categoria. Repertório IOB de jurisprudência: trabalhista e previdenciário, São Paulo, n. 7, p. 212, abr. 2011.

25 Art. 10. Os ajustamentos de salário fixados em decisões da Justiça do Trabalho, aprovados em julgamento de dissídios coletivos ou em acordos homologados, serão aplicados, automaticamente, nas mesmas condições estabelecidas para os integrantes das categorias profissionais litigantes ou interessadas, aos empregados das próprias entidades suscitantes e suscitadas, observadas as peculiaridades que lhes sejam inerentes, ficando, desde logo, autorizado o reajustamento das respectivas verbas orçamentárias.

26 BRASIL. Tribunal Regional do Trabalho (3. Região). Recurso Ordinário. RO 0000200-29.2011.5.03.0061. Belo Horizonte, 23 de abril de 2012. Disponível em: < http://trt-3.jusbrasil.com.br/noticias/3095281/principio-da-unicidade-sindical-nao-se-aplica-afederação>. Acesso em 30.05.2014

Conforme esclareceu o juiz sentenciante, o artigo 534 da CLT dispõe que os sindicatos podem se organizar em federações, desde que representem a maioria absoluta de um grupo de ocupações ou profissões iguais, semelhantes ou conexas, observado o número mínimo de cinco sindicatos. Já o parágrafo primeiro do mesmo dispositivo possibilitou a criação de nova entidade de segundo grau. A condição é que seja mantida a filiação de cinco sindicatos na federação já existente. Ou seja, a filiação é voluntária e não obrigatória. "O termo filiação traz ínsita a ideia de voluntariedade, significando agregar-se, unir-se, inscrever-se como sócio ou membro, sempre de forma espontânea, sendo que se a obrigatoriedade fosse a regra, o termo filiação não teria sido introduzido na norma supra, e sua redação seria, necessariamente outra”, ressaltou. 
pulsória a todos de uma categoria, aplicando-se as mesmas regras do enquadramento sindical. Sua base legal é o art. 580 da CLT. A contribuição sindical é o nome dado ao que era o imposto sindical, e a denominação atual surgiu com o Decreto-Lei no 27, de 14 de novembro de 1966.

A contribuição sindical é paga uma vez por ano. Em relação aos empregadores corresponde a um dia de salário, qualquer que seja a forma da referida remuneração. Neste sentido, os empregadores são obrigados a descontar, da folha de pagamento de seus empregados, relativa ao mês de março de cada ano, a contribuição sindical devida aos respectivos sindicatos.

Em relação aos empregadores, a contribuição será proporcional ao capital social das empresas, registrada na Junta Comercial ou órgãos equivalentes, mediante a aplicação de alíquotas, conforme tabela progressiva prevista em lei. ${ }^{27}$

Estabelecidos alguns pressupostos legais e teóricos, o próximo passo é a análise de dados do cadastro sindical e derivados, com os quais se reúnem elementos que subsidiam a respostas das questões formuladas inicialmente.

\section{Cadastro e controle de legalidade das entidades sindicais}

Nesta segunda parte do artigo, delineiam-se possibilidades de respostas às questões formuladas na introdução — que são reapresentadas nesta seção — em função de dados públicos coletados e agrupados em confronto das situações fáticas identificadas com a regras e entendimentos sobre a unicidade e cadastro.

Uma primeira análise consiste na análise cadastral. No site do Ministério do Trabalho e Emprego (MTE) podem ser encontrados 15.228 sindicatos $^{28}$, sendo 80 inativos e os demais em situação ativa. São 3.265 sindicatos de empregados e os demais de empregados autônomos [303], rural [4.179], servidores públicos [1.501], categoria diferenciada [473], empregados [4.764], empregados e avulsos [3], oficial econômico [5], oficial profissional [17], profissionais liberais [450]). A Solicitação de Registro Sindical é regida pela Portaria MTE $n^{\circ} .186 / 08$ e é realizada por meio de formulário eletrônico e segundo o site $e^{29}$ são requeridos algumas características mínimas do Cadastro Nacional da Pessoa Jurídica (CNPJ) junto à receita. Um dos requisitos para o cadastramento do sindicato é a convocação de Assembleia Geral com propósito específico inclusive como publicação no Diário Oficial da União (DOU). Desde 2005 foram encontrados 7.292 convocações com esse propósito ${ }^{30}$, o que de certa forma indica um grande crescimento na criação de sindicatos, já que representariam quase metade dos sindicatos reconhecidos. Também deve-se destacar que, no mesmo período, foram realizadas $9.580^{31}$ convocações de assembleias para outros fins tais como ampliação de base territorial, filiação a federação/confederação/central. De certa forma, tais dados demonstram uma acelera-

27 FIORAVANTE, Tamira Maira; ALOUCHE, Luiz Fernando. Fontes de custeio dos sindicatos no Brasil: panorama geral. Jornal trabalhista Consulex, Brasília, v. 28, n. 1366, p. 4, mar. 2011.

28 BRASIL. Ministério do Trabalho e Emprego. Registro Sindical. Disponível em: <http://www3.mte.gov.br/cnes/reg_sindical. asp>. Acesso em: 24 jul. 2012.

29 BRASIL. Ministério do Trabalho e Emprego. Cadastro Nacional de Entidades Sindicais. Disponível em: < http://portal.mte.gov. br/cnes/registro-sindical-sc.htm>. Acesso em: 30 jul. 2012.

Uma entidade só pode iniciar uma Solicitação de Registro Sindical se ela possuir um número de CNPJ com situação ATIVA junto à Receita Federal e com a Natureza Jurídica cadastrada como Entidade Sindical (código 3131), Associação (código 3026) ou Outras Formas de Associação (código 3999).

30 BRASIL. Tribunal de Contas da União. Análise de dados públicos.

Pesquisa realizada em 27-julho-2012, chaves "Assembléia Geral sindicato data:[2005 TO 2012] fundação". Disponível em: $<$ https: / contas.tcu.gov.br/adp/Web/busca/results.jsp?maxresults $=20 \& q u e r y=A s s e m b l \%$ E $9 \mathrm{ia}+$ Geral + sindicato + data $\% 3 \mathrm{~A} \% 5 \mathrm{~B}$ $2005+\mathrm{TO}+2012 \% 5 \mathrm{D}+$ funda $\% \mathrm{E} 7 \% \mathrm{E} 3 \mathrm{o}>$.

Para efeitos de comparação tem-se que entre anos de 2000 e 2004 foram apenas 171 documentos do tipo publicados no Diário Oficial da União.

31 BRASIL. Tribunal de Contas da União. Análise de dados públicos.

Pesquisa realizada em 27-julho-2012, chaves de pesquisa: "Assembleia Geral sindicato data:[2005 TO 2012] -indexa:fundação “

Disponível em: < https:// contas.tcu.gov.br/adp/Web/busca/results.jsp? maxresults=20\&query=Assembl\%E9ia + Geral + sindica to + data $\% 3 \mathrm{~A} \% 5 \mathrm{~B} 2005+\mathrm{TO}+2012 \% 5 \mathrm{D}+$-indexa $\% 3 \mathrm{Afunda} \% \mathrm{E} 7 \% \mathrm{E} 3 \mathrm{O}>$. 
ção na busca do reconhecimento dos sindicatos, sua oficialização, o que lhe permite receber a contribuição sindical. A seguir apresenta-se tabela com algumas classificações na estrutura sindical, que permite entender a complexidade da própria estrutura. É importante ressaltar que algumas classificações se interpenetram (especialmente grupo e classe), assim como existem algumas não classificações.

Tabela 1: visão geral da classificação das entidades sindicais.

\begin{tabular}{|c|c|c|c|c|}
\hline $\begin{array}{l}\text { Grau da } \\
\text { entidade }\end{array}$ & $\begin{array}{c}\text { Área } \\
\text { econômica }\end{array}$ & Grupo & Abrangência & Classe \\
\hline $\begin{array}{c}38 \\
\text { Confederações }\end{array}$ & $\begin{array}{c}2 \text { rurais, } 36 \\
\text { urbanos }\end{array}$ & $\begin{array}{l}10 \text { empregador, } \\
28 \text { trabalhadores }\end{array}$ & Base nacional & $\begin{array}{c}2 \text { profisisonais liberais/17 Oficial } \\
\text { Profissional/ } 6 \text { oficial econômico/ } 8 \\
\text { empregados/3 empregadores }\end{array}$ \\
\hline 524 federações & $\begin{array}{l}44 \text { rurais, } \\
480 \\
\text { urbanos, } \\
\text { sendo } 5 \\
\text { inativos }\end{array}$ & $\begin{array}{l}157 \text { empregador, } \\
365 \text { trabalhadore }\end{array}$ & $\begin{array}{l}331 \text { estaduais, } 97 \\
\text { interestaduais, } 5 \\
\text { intermunicipais, } 1 \\
\text { municipal (FIBRA } \\
\text { - Federação das } \\
\text { Indústrias de } \\
\text { Brasília),90 sem } \\
\text { classificação } \\
\end{array}$ & $\begin{array}{l}44 \text { rurais, } 3 \text { de trabalhores avulsos, } \\
37 \text { de servidores públicos, } 31 \\
\text { profissionais liberais, } 12 \text { categoria } \\
\text { diferenciada, } 7 \text { de autônomos, } 110 \\
\text { não se aplica, } 258 \text { empregados, } 21 \\
\text { empregadores, } 1 \text { sem classificação }\end{array}$ \\
\hline $\begin{array}{c}14.665 \\
\text { sindicatos }\end{array}$ & $\begin{array}{l}4.134 \\
\text { rurais, } \\
10.531 \\
\text { urbanos, } \\
\text { sendo } 75 \\
\text { inativos }\end{array}$ & $\begin{array}{l}4.687 \\
\text { empregadores } \\
\text { e } 9.978 \text { de } \\
\text { trabalhadores }\end{array}$ & $\begin{array}{l}6.780 \text { municipais, } \\
4.340 \text { intermunicipais, } \\
151 \text { interestadual, } \\
3.313 \text { estaduais, } 81 \\
\text { sem classificação }\end{array}$ & $\begin{array}{c}296 \text { de autônomos, } 461 \text { de } \\
\text { categorias diferenciadas, } 3.184 \\
\text { de empregadores, } 4.498 \text { de } \\
\text { empregados, } 3 \text { de avulsos, } 7 \text { não se } \\
\text { aplica ou sem classificação, } 417 \text { de } \\
\text { profissionais liberais, } 4.134 \text { rurais, } \\
1464 \text { servidores públicos, } 201 \text { de } \\
\text { trabalhadores avulsos }\end{array}$ \\
\hline
\end{tabular}

Fonte: dados coletados pelo autor.

A corrida dos sindicatos por sua oficialização e participação na contribuição sindical de cerca de um bilhão de reais/ano não enseja, como pode ser avaliado por diversas heurísticas e cruzamentos de dados, que as muitas entidades estejam mais representativas ou preocupadas com adequação às leis. Na mesma linha, também se menciona o papel do MTE, que mesmo só avaliando aspectos formais e sem adentrar no que seria o âmbito de autonomia das entidades sindicais, não utiliza mecanismo que seria mais eficiente e apto a manter o cadastro atualizado. Em relação à atualização do cadastro, deve-se mencionar que tais dados são utilizados para legitimar diversos fins, como a distribuição das contribuições sindical e publicidade das representantes das entidades.

Acerca do cadastro em si, pode-se mencionar que o MTE não exige o uso de certificado e assinaturas digitais para o cadastro de entidades sindicais, apesar de outros órgãos exigirem o uso da tecnologia de todas pessoas jurídica ${ }^{32}$, o que foi a grande barreira de entrada para o uso da tecnologia citada ${ }^{33}$. Considerando o

32 BRASIL. Receita Federal do Brasil. Instrução Normativa RFB no 969, de 21 de outubro de 2009, Dispõe sobre a obrigatoriedade de apresentação de declarações com assinatura digital, efetivada mediante utilização de certificado digital válido, nos casos em que especifica. DOU de 22.10.2009

Art. $1^{\circ}$ A partir de $1^{\circ}$ de janeiro de 2010, para a transmissão de declarações e demonstrativos pelas pessoas jurídicas tributadas com base no lucro real, no lucro presumido ou no lucro arbitrado, é obrigatória a assinatura digital, efetivada mediante utilização de certificado digital válido.

Art. $1^{\circ}$ É obrigatória a assinatura digital efetivada mediante utilização de certificado digital válido, para a apresentação, por todas as pessoas jurídicas, exceto as optantes pelo Regime Especial Unificado de Arrecadação de Tributos e Contribuições devidos pelas Microempresas e Empresas de Pequeno Porte (Simples Nacional), das declarações e dos demonstrativos a seguir relacionados: (Redação dada pela Instrução Normativa RFB no 995, de 22 de janeiro de 2010)

CIRCULAR N 547, DE 20 DE ABRIL DE 2011

Estabelece a certificação digital emitida no modelo ICP-Brasil, de acordo com a legislação em vigor, como forma de acesso ao canal eletrônico de relacionamento Conectividade Social.

33 Além da Receita Federal, que paulatinamente tem exigido certificação digital de pessoas jurídicas e físicas, também Caixa 
volume de entidades bem como a necessidade de manter atualizados diversos dados, por força de diversas diplomas legais em situações que não só a unidade e contribuição sindical ${ }^{34}$, tais como endereços, membros, mandatos da diretoria ${ }^{35}$, área de atuação até filiação sindical parece ser prudente que se exija o uso dessa solução tecnológica, uma vez que a ausência dessa solução poderia ocasionar lesão à confiabilidade, veracidade e não repúdio das informações oficiais. A emissão dos certificados ICP-Brasil requer apresentação de certidão do registro em Registros Civis de Pessoas Jurídicas, que a pessoa física responsável tenha poderes conforme o estatuto/contrato ou assembleia e que haja conferência personalíssima dos documentos de identidade apresentados. Tais providência seriam salutares e representam elementos exigíveis de quaisquer outras corporações e podem embasar discussões sobre a razoabilidade do afastamento de padrões mínimos de fiscalizados, neste caso com destaque ao cadastro em si, que não é considerado incompatível com a Carta Magna.

Além da recepção dos dados, o cadastro falha em apresentar os dados gerenciados de forma completa e eficaz para acompanhamento pelos cidadãos. Um exemplo é a não disponibilização dos CPF dos dirigentes sindicais, mesmo sendo requerido seu cadastro ${ }^{36}$. Um dos usos da informação seria o de verificar se existem pessoas atuando em diversos sindicatos, algo não estritamente proibido mas, que possivelmente indica falha de representatividade. Mesmo sendo possível que uma pessoa exerça cargos diretivos em diversos sindicatos, não parece ser razoável haja vista a quantidade de irregularidade que podem ser verificada e a falta de representatividade. ${ }^{37}$ Nos 15.228 sindicatos são indicadas 223.702 dirigentes, com números que variam de 1 a 370 pessoas por entidade. Ocorre que existem nada menos que 24.797 nomes iguais em mais de uma entidade, ou seja, ao menos $22 \%$ dos dirigentes se dividem. Por certo a homonímia não enseja serem as mesmas pessoas, algo que poderia ser dirimido com o CPF. A própria desatualização dos dados pode contribuir para isso, mas é um dado que mostra que pode ser mais importante para criar a estrutura mínima de um sindicato que permita seu enquadramento que a representação dos interesses das classes, em muitos casos. Dados de CPF seriam úteis também para se avaliar algo que envolvesse a ficha limpa dos dirigentes, e

Econômica Federal em operações do FGTS patromais tem feito tal exigência. Tais medidas fazem com que seja imperativa de uma empresa que opere dentro da legalidade obtenha certificação digitais. As exceções são procedimentais, como por exemplo o sócio controlador de uma scoiedade empresário que tem certificado digital em nome próprio e pode realizar certas operações dessas forma.

34 BRASIL. Ministério do Planejamento, Orçamento e Gestão. Secretaria de Recursos Humanos Portaria Normativa No 1 , de 15 de abril de 2011.

Disponível em: <http://www.in.gov.br/imprensa/visualiza/index.jsp?jornal=1\&pagina=89\&data=18/04/2011>.

Considerando

$[\ldots]$

II -a necessidade de recadastramento das instituições consignatárias, a ser realizado anualmente, como condição para a habilitação para a operação de consignações em folha de pagamentos no Sistema Integrado de Administração de Recursos Humanos - SIAPE; Anexo II : RELAÇ̃̃O DE DOCUMENTOS EXIGIDOS PARA RECADASTRAMENTO

2. Aos sindicatos ou associações de caráter sindical:

2.1. Para rubricas de Mensalidade:

2.1.1. Ata de eleição dos membros da atual diretoria da instituição, devidamente averbada no Cartório de Registro Civil das Pessoas Jurídicas;

2.1.2. Ata de posse dos membros da atual diretoria da entidade, devidamente averbada no Cartório de Registro Civil das Pessoas Jurídicas;

2.1.3. Ata da última assembléia, ou documento equivalente, em que foi deliberado o valor da mensalidade, e o respectivo edital de convocação;

2.1.4. Ata do Sindicato ou Federação que autorizou a associação a atuar como seção sindical; e 2.1.5. Declaração de que possui registro sindical, emitida pelo Ministério do Trabalho e Emprego, conforme exigência legal.

35 Por exemplo, 2.640 entidades têm registrada diretoria com data de término de mandato já vencida, até junho de 2012 e alguns sem atualização desde 2005.

36 BRASIL. Ministérios do Trabalho e Emprego. Portaria MTE n 186, DE 10 DE ABRIL DE 2008.

Art. $2^{\circ}[\ldots]$

III - ata da assembléia geral de alteração estatutária da entidade e eleição, apuração e posse da diretoria, com a indicação do nome completo e número do Cadastro Pessoas Físicas - CPF dos representantes legais da entidade requerente, acompanhada de lista contendo o nome completo e assinatura dos presentes; e

37 Uma explicação para a criação de sindicatos assim seria simplesmente ocupar espaço em âmbito municipal, impedir novas divisões e garantir a contribuição sindical. 
aumentar o esclarecimento dos representados. É certo que cabe aos trabalhadores elegerem seus representantes, mas como se trata se distorções no sistema e em muito casos os formalmente representados sequer são chamados a exercer seus direito de voto $^{38}$, parece que a existência de informação cadastral atualizada dos dirigentes é útil.

Também é determinação legal que seja dada a publicidade registral aos dirigentes de associações, por meio do registro do estatuto e averbações das atualizações e atas em Registro Civil de Pessoas Jurídicas (CC/2002 art. 45 e CLT art. 511). Deve-se pontuar que a estrutura dos registro civis é mais capilar e distribuída que a da Juntas Comerciais, em que se registram as sociedade empresárias: isto traz consequências e na forma atual uma delas é a maior dificuldade ou custo em se obter certidões atualizadas da situação da associação, um requisito básico para conhecer de sua representação legal e efeitos perante terceiros. Para efeito de comparação, pode-se mencionar que a Junta Comercial de São Paulo, autarquia que permite a visualização dos registros recentes ou já digitalizados sem ônus ${ }^{39}$. Já os emolumentos nos registros civis são fixados em lei estadual e hoje não há central para emissão online dos documentos ou em localidade diversa. Tais elementos compõem um cenário que indica déficit de informação sobre os dirigentes sindicais, o que leva a situações em que a representação dos empregados é deixada de lado em busca do cumprimento de requisitos formais para recebimento de verbas compulsórias.

Outra crítica ao cadastro é a não disponibilização dos documentos que são enviados. Apesar de existirem diversos requisitos formais, o site apenas apresenta extratos das requisições. Há 5.864 entidades com situação ativa em que o último histórico processual não é ativo, válido ou com solicitação concluída (tais como "Não Válida" [4.658], "Em Conferência” [313], "Aguardando Correção [45]", "Solicitação não concluída" [848]). Mesmo em muitos casos de validade, houve impugnações em que somente se pode observar um extrato. Antes de 2010, ocorriam menos de dez análises por dia, em 2011/2012 o número se elevou, e se observam picos em que mais de 100 pareceres foram exarado (por exemplo, 103 em 11-julho-2012). Em virtude da apresentação de meros extratos, fica difícil analisar se houve aumento de eficiência ou mera análise mais rasa dos requisitos.

Tal situação também pode indicar pouca atuação de grande parte dos sindicatos, vide o número de convenções e acordos coletivos de trabalho. A despeito da previsão de publicação ${ }^{40}$, encontram-se poucos documentos no site do Ministério do trabalho e Emprego (MTE) e da limitação do prazo dos acordos e convenções coletivas encontram-se documentos no site do MTE em número bem menor que o de sindicatos, sendo que muitos se referem a acordos ou convenções não mais vigentes, algo que afeta a publicidade e previsibilidade, mas que não possui sanção legal específica. Uma busca no site por "convenção coletiva" revela 840 documentos e a busca por "acordo coletivo" traz menos de $2.740^{41}$. Além de alguns retornos não serem documentos, percebe-se que muitos já não se encontram vigentes. Há que se reconhecer que alguns simplesmente não publicam os documentos e que, em muitos casos, ocorrem intervenções normativas da Justiça do trabalho, algo que ajuda a minar a função sindical. De qualquer forma, tais dados são subsídios para que se questione a manutenção de verba compulsória para sindicato que não busca cumprir elementos daquilo que é sua finalidade precípua ${ }^{42}$. É importante salientar que um sindicato pode exercer outras funções, mas a ausência de

38 Há obrigação de publicação de edital no Diário Oficial da União, o que gera publicidade presumida, mas nada para efetivamente provar que um número expressivo de trabalhadores se manifestou.

39 Item 16.1.2 Certidão Simplificada - fornecimento pela internet e item 16.2.9 Download pela internet de imagem digitalizada (quando disponível), da TABELA DE PREÇOS DA JUNTA COMERCIAL DO ESTADO DE SÃO PAULO - JUCESP. Disponível em: <http://www.jucesp.fazenda.sp.gov.br/downloads/valores_servicos_completo.pdf>. Acesso em: 20 fev. 2013.

40 CLT Art. 614 - Os Sindicatos convenentes ou as empresas acordantes promoverão, conjunta ou separadamente, dentro de 8 (oito) dias da assinatura da Convenção ou Acordo, o depósito de uma via do mesmo, para fins de registro e arquivo, no Departamento Nacional do Trabalho, em se tratando de instrumento de caráter nacional ou interestadual, ou nos órgãos regionais do Ministério do Trabalho e Previdência Social, nos demais casos.

41 Busca realizada em http://portal.mte.gov.br/main.jsp no dia 29-jul-2012

42 CLT Art. Art. 513. São prerrogativas dos sindicatos :

a) representar, perante as autoridades administrativas e judiciárias os interesses gerais da respectiva categoria ou profissão liberal 
negociações coletivas é forte indício de que não exerce suas atividade típicas e precípuas. E o quadro se torna pior se, além de não representar, receber as contribuições, o que em algum sentido se torna barreira de entrada para alguma associação que efetivamente queira representar a categoria daqueles filiados. No que tange ao controle dos dados para distribuição da contribuição sindical, deve-se destacar grande número de sindicatos sem federações, confederações e centrais. O problema em si não é ausência, mas a quantidade e a distinção entre a não existência e a não declaração. São 2.670 entidades que não declararam federação, 4.495 que não declaram confederação e 2.649 que não declararam central sindical. Sob o ponto de vista cadastral, é mais uma fragilidade que não pode ser respaldada pela inércia do MTE e negligência dos sindicatos. A existência da estrutura piramidal é prevista em lei, se coaduna com divisão de responsabilidades. Pode-se perguntar se há espaço de liberdade sindical negativa de um sindicato em relação a outro. De certa forma, dado um sindicato e uma base territorial, havendo federação ou confederação não haveria opção de escolha diversa, mas talvez exista a opção de não filiação, mesmo que não expressa em lei. Mesmo se admitindo tal hipótese, há que se distingui-la do mero desconhecimento da situação do sindicato e buscar maior abrangência e adequação na informação cadastral deve ser precisa e atualizada, e envolve tais relações.

Além do viés cadastral, o cenário leva a uma questão de conflito com princípio da legalidade e possivelmente crime fiscal (excesso de exação, algo em que se precisaria demonstrar o dolo, dentre outros aspectos). A repartição das receitas depende da configuração de filiações, e, inclusive, há verbas que deveriam de ser destinadas aos sindicatos, mas é desviada para a "Conta Especial Emprego e Salário".

Originalmente a repartição observava a seguinte repartição: 5\% para a confederação correspondente; $5 \%$ para a federação, $15 \%$ para a confederação correspondente, $60 \%$ para o sindicato respectivo e $20 \%$ para a "Conta Especial Emprego e Salário". Na inexistência de confederação, o percentual a ela definida seria atribuído à federação. Em caso de federação não organizada para a categoria, o percentual que lhe seria devido transmitir ao sindicato da categoria econômica ou profissional. Na falta de entidades sindicais de grau superior ou de sindicato organizado, os percentuais a ele destinados seriam transferidos para a "Conta Especial Emprego e Salário". Com a regulamentação legal das Centrais Sindicais pela Lei $\mathrm{n}^{\circ}$ 11.648, em 31 de março de 2008, parte da receita da contribuição sindical dos trabalhadores passa a ser destinada a elas, no montante de $10 \%$ do valor arrecadado, com idêntica redução da a "Conta Especial Emprego e Salário" (grifo nosso). ${ }^{43}$

Mesmo que haja decisão do STF legitimando repasses à conta gerida pelo $\mathrm{MTE}^{44}$, tal mecanismo não pode ser justificado por erro cadastral, podendo caracterizar inclusive desvio de recurso. Basicamente, surge uma situação em que um cadastro mal gerido propicia ao gestor auferir mais recursos. Do ponto de vista tributário, um erro acidental, não inescusável, implicaria na tipicidade de um comportamento enquadrado como excesso de exação.

Com os dados de CNPJ das entidades sindicais, é possível acessar bases públicas referentes a certidões de regularidade fiscal e se avaliar os resultados. Mesmo que a $\mathrm{CF} / 88$ preveja imunidade das entidades sindicais de trabalhadores [art. 150, VI, c], isto não as exime de pagar contribuições previdenciárias e Fundo de Garantia do Tempo de serviço (FGTS) de seus próprios empregados. ${ }^{45}$ No entanto, a Tabela 2 evidencia que a maioria das entidades não alcança situação que permita a emissão da certidão negativa. Observa-se ainda que mais de

ou interesses individuais dos associados relativos á atividade ou profissão exercida;

b) celebrar contatos coletivos de trabalho;

43 REIS, Daniela Muradas. A imposição da contribuição sindical e o princípio da liberdade associativa: reflexões sobre o regime democrático e o financiamento sindical brasileiro. Repertório IOB de jurisprudência: trabalhista e previdenciário, São Paulo, n. 5, p. 156, mar. 2012

44 BRASIL. Supremo Tribunal Federal. AGRg no RE279.393/SC, 2a Turma, julgado em 06-set-2005, rel. Min. Carlos Velloso, DJ, 30-sete-2005. p. 48.

45 Exigência de certidão negativa da previdência social: art. 47, I, com destaque à alínea "a": na contratação com o Poder Público e no recebimento de benefícios ou incentivo fiscal ou creditício concedido por ele;

Exigência de certidão de FGTS: art. 27 da Lei 8.036/1990, com destaque à alínea "c": obtenção de favores creditícios, isenções, subsídios, auxílios, outorga ou concessão de serviços ou quaisquer outros benefícios concedidos por órgão da Administração Federal, Estadual e Municipal, salvo quando destinados a saldar débitos para com o FGTS; 
5\% de sindicatos que jamais recolheram FGTS, pois a contrário senso, se tivessem feito e apresentado GFIP, estariam na situação de cadastrados junto à Caixa Econômica Federal. O que se considera é que para representar existe um trabalho rotineiro, e por isso a necessidade de que haja empregados. Podem não ser próprios, é verdade, mas de certa forma, terceirizar é contrário à premissa defendida por muitas associações de trabalhadores, exatamente pela precarização. Outra opção é que o sindicato seja efetivamente pequeno em número de representados e que não justifique manter estrutura fixa, algo que é possível, mas cuja solução pode passar por união com outras entidades. Os únicos que poderiam não recolher impostos, obrigatoriamente, seriam os dirigentes não empregados. Além dessas opções, remanesce a questão de existirem pendências e falta de recolhimento em relação aos próprios empregados, e que também são (parcela) dos representados. É indício de problemas como entidades "fantasmas" ou de desvio de moralidade/legalidade, e que ainda resvala em questionamentos sobre até que ponto um sindicato sem trabalhadores poderia representar a categoria ${ }^{46}$.

Tabela 2: Dados de Certidões Fiscais dos sindicatos, entidades sindicais e associativas - julho $2012^{47}$.

\begin{tabular}{|c|c|c|c|}
\hline Situação & $\begin{array}{l}\text { Certidão } \\
\text { FGTS }\end{array}$ & $\begin{array}{c}\text { Certidão } \\
\text { Previdenciária }\end{array}$ & Notas \\
\hline Sem certidão & & 6.182 & $\begin{array}{l}6.129 \text { referentes a sindicatos ativos, sendo } 4.558 \\
\text { de trabalhadores e } 1.571 \text { de empregadores }\end{array}$ \\
\hline $\begin{array}{l}\text { Certidão Positiva } \\
\text { FGTS } \\
\end{array}$ & 3.063 & & $\begin{array}{l}3.057 \text { referentes a sindicatos ativos, } 2.442 \text { de } \\
\text { sindicatos de trabalhores e } 615 \text { de empregadores }\end{array}$ \\
\hline Erro ao baixar & 10 & 3 & $\begin{array}{c}\text { Erros de FGTS em sindicatos ativos, sendo } \\
8 \text { em entidades de trabalhadores, já as } 3 \\
\text { previdenciárias são em sindicatos ativos. }\end{array}$ \\
\hline $\begin{array}{l}\text { Emitida há mais } \\
\text { de } 6 \text { meses }\end{array}$ & 4.022 & 6.153 & $\begin{array}{c}\text { FGTS: } 28 \text { de entidades inativas das demais } 2.865 \\
\text { de trabalhadores. } \\
\text { Previdência: } 25 \text { por entidades inativas, e dentre } \\
\text { as ativas, } 4.347 \text { por entidades de trabalhadores }\end{array}$ \\
\hline Não cadastrada & 767 & & $\begin{array}{l}21 \text { de sindicatos inativos e } 746 \text { em ativos, sendo } \\
549 \text { em sindicatos de trabalhadores e } 197 \mathrm{em} \\
\text { sindicatos de empregadores. }\end{array}$ \\
\hline $\begin{array}{l}\text { Emitida há } \\
\text { menos de } 6 \\
\text { meses }\end{array}$ & 7.365 & 2.889 & $\begin{array}{c}\text { FGTS: } 7.340 \text { em entidades ativas e } 4.433 \mathrm{em} \\
\text { entidades de trabalhadores. Previdência } 2887 \\
\text { em entidades ativas e } 1400 \text { em entidades de } \\
\text { trabalhores } \\
2.542 \text { na interesseção. }\end{array}$ \\
\hline $\begin{array}{l}\text { Certidão negativa } \\
\text { FGTS (validade } \\
\text { maior ou igual } \\
\text { data da consulta, } \\
\text { validade de } 30 \\
\text { dias) }\end{array}$ & 2.111 & & $\begin{array}{c}3 \text { em entidades inativas, } 1.087 \text { em entidades de } \\
\text { trabalhadores }\end{array}$ \\
\hline
\end{tabular}

Fonte: dados coletados pelo autor.

46 Pode-se imaginar, no extremo, terceirização sem recebimento de remuneração alguma por parte dos dirigentes. Mesmo assim tal situação apontaria para necessidade de ajustes na base de representação. Na generalidade dos casos, todavia, tais constatações apontam para sindicatos meramente formais (de fachada, fantasmas) e que serviriam apenas pata angariar contribuições obrigatórias. Um questionamento que se pode fazer é se a situação meramente formal de um sindicato se confunde com a situação de fato, de movimento social ou se poderiam ser considerados não sindicatos, com consequente impacto em registro, contribuição compulsória e proteção legal.

47 Certidões da Previdência baixadas em 24 e 25 de Julho de 2012 em http://www010.dataprev.gov.br/CWS/BIN/cws_mv2. asp?CONTEXTO/CND/ACNT1004.

Certidões do Fundo de Garantia do Tempo de Serviço (FGTS) baixadas nos dias de 25 a 27 de Julho de 2012 em https://www.sifge. caixa.gov.br/Cidadao/Crf/Crf/FgeCfSConsultaRegularidade.asp. 
Deve-se pontuar que, em alguns casos, a existência de certidão positiva ou sua ausência podem decorrer de questões formais, desencontros de contas ou informações prestadas. Por outro lado, a emissão de certidões também se funda nas declarações das empresas, e quando são declarados menos empregados e as contas em algum nível fecham os sistemas da Receita/Previdência/FGTS, não acusam irregularidade. Mesmo assim é uma informação relevante de que apenas 14\% e 20\% das entidades sindicais possuírem certidões válidas para o FGTS e Previdência Social, e que a interesseção dessas duas variáveis esteja no patamar de 7\%. São elementos importantes para aferição do grau de legitimidade para que recebam verbas públicas e/ou parafiscais. Tais divergências são mais que meras irregularidades e representam impeditivos ao recebimento de verbas públicas. De certa forma, é importante se perquirir qual a natureza jurídica das verbas compulsórias e destacar que mesmo entes públicos ficam proibidos de receber repasses voluntários ou firmar convênios na ocorrência de falta de certidões como as mencionadas.

Não se deve, todavia, considerar que tais índices sejam exclusivos das entidades sindicais. Empresas e governos são recalcitrantes nesse comportamento, o que pode evidenciar que o sistema legal tem de ser aperfeiçoado e também indica que o controle sobre as arrecadações é frágil. Do ponto de vista sindical, a contradição seja talvez maior, uma vez que seus próprios empregados não podem participar de outros sindicatos (sindicato dos trabalhadores de sindicato), e que nesse caso teriam mais força para exigir a regularidade dos procedimentos.

Acerca da possível fragilidade das certidões, destaca-se que a visão global das receitas e despesas seria importante para aferição mais precisa. As entidades sindicais em regras não são obrigadas à realização da escrituração digital, $\mathrm{SPED}^{48}$. O uso de escrituração digital também teria o condão de propiciar a análise das contas em algum grau de todas entidades, o que por uma lado dificultaria a situação das que não se relacionam a com sua finalidade precípua e por outro lado aumentariam a legitimidade das demais. Seria forma de se avaliarem pagamentos, não se de impostos, mas distorção em pagamentos de dirigentes. $\mathrm{O}$ reconhecimento da necessidade de segregação de verbas públicas de outras fontes de financiamento das entidades sindicais é evidenciado por recente Instrução Normativa do MTE ${ }^{49}$. Outrossim, acerca de valores recebidos pelos sindicatos, se destaca que muitas rubricas não constam do Portal da Transparência, pois seriam repasses feitos diretamente pela Caixa Econômica Federal aos sindicatos em contas vinculadas. Não deixam de ser, todavia, valores de um tributo ${ }^{50}$.

\section{Conclusões}

De início o trabalho destacou a criação do imposto sindical, ainda no Estado Novo e sua ampliação de uma contribuição restrita aos filiados para abarcar todos os que compunham uma categoria profissional ou econômica. Também se vinculou a possibilidade de recolhimento de contribuições ao seu reconhecimento oficial do sindicato pelo Estado, o que reforçou a ingerência estatal sobre as entidades sindicais.

$\mathrm{Na}$ sequência, mostra-se que a sistemática da contribuição, exceto pela mudança de nome de imposto

48 BRASIL. Receita Federal do Brasil. Instrução Normativa RFB n. 787, de 19 de novembro de 2007. Institui a Escrituração Contábil Digital.

49 Instrução Normativa MTE No 1/2011 - PLANO DE CONTAS ENTIDADE SINDICAL - "CONTA CONTRIBUIÇÃO SINDICAL" - SEGREGAR RECEITA/DESPESA - OBRIGATORIEDE.

Constituição Federal, e em atendimento ao determinado no item 9.2 do Acórdão TCU no 1663/2010 - Plenário, abaixo transcrito:

"9.2. determinar ao Ministério do Trabalho e Emprego que, no prazo de sessenta dias, a contar da ciência, expeça orientação formal dirigida às entidades sindicais no sentido de que promovam ajustes em seus planos de contas de modo a segregar contabilmente as receitas e as despesas decorrentes da contribuição sindical instituída nos arts. 578 a 610 da CLT, com as alterações da Lei 11.648/2008, a fim de assegurar a transparência e viabilizar o controle da aplicação de recursos públicos.” Orienta:Art. $1^{\circ}$ As entidades sindicais deverão promover ajustes em seus planos de contas, de modo a segregar contabilmente as receitas e as despesas decorrentes da contribuição sindical, a fim de assegurar a transparência.

50 BRASIL. Controladoria Geral da União. Portal da Transparência. Disponível em: < http://www.portaltransparencia.gov.br/>. Acesso em: 10 nov. 2014. 
para contribuição sindical, resistiu a diversos projetos ou estudos, desde os governos militares até a democracia. Nessa disputa de posições se destaca a posição contraditória das Centrais Sindicais, que consideravam a contribuição social anacrônica e com a Lei 11.648/2008 se tornaram grandes beneficiárias da contribuição que combatiam. A referida lei teve mérito de reconhecer as centrais, que no modelo sindical brasileiro têm o papel de integrar pleitos de diversas categorias, mas ao mesmo tempo aprofundou a contradição entre liberdade sindical e contribuição compulsória bem como recebeu diversas críticas pelo afastamento do controle sobre os recursos recebidos sob a alegação, no veto, de que isso representaria restrição à autonomia das entidades.

Na segunda parte do artigo, foram destacadas informações baseadas em cruzamentos dos dados constantes do site do Ministério do Trabalho e Emprego (MTE) sobre os registros sindicais, Diário Oficial da União e certidões fiscais relativas a contribuições previdenciárias e do FGTS. O cadastro dos sindicatos serve para indicar filiação na hierarquia sindical, indicativos do processamento de registro no MTE, área de atuação, classificação, dirigentes, número do Cadastro Nacional de Pessoas Jurídicas (CNPJ). Com esse último, é possível o que se baixe e interprete as certidões fiscais dos tipos referidos, que podem indicar desde débitos ou omissões, passando pela absoluta falta de contribuições, até a regularidade sob aspectos formais. É importante a menção a serem diversos aspectos formais para evidenciar que a presença de certidões fiscais, que em diversos casos é pré-requisito para recebimento de verbas ou benesses públicas, é um filtro simples, fundando em dados públicos e abertos e que só adentra a alguns aspectos da contabilidade das entidades referidas.

Mesmo com tais limitações, o número de entidades que não apresentam a regularidade fiscal representa mais de $80 \%$ das entidades sindicais cadastradas, o que é um número que extensão causa preocupações e revela fragilidades, de fiscalização, ou da própria atuação sindical ${ }^{51}$. Tal situação indica que essa parcela das entidades ou não pagam tais impostos e contribuições regularmente, ou não cumprem requisitos e declarações exigidos de qualquer pessoa jurídica. Trata-se de um cumprimento direto de legalidade, algo que se destaca no artigo, pois não se pode confundir autonomia com conivência com descumprimento de leis. As certidões de previdência e FGTS indicam que os próprios sindicatos apresentam problemas em cumprir as exigências legais, o que pode indicar um problema estrutural. É interessante notar que mesmo que tais informações refiram-se a dados cujos documentos são públicos, muitas vezes a forma pela qual são disponibilizados representa um empecilho a muito de seus usos e cruzamentos. No caso em tela, basta imaginar que o preenchimento de dados de formulário Web, execução, verificação dos documentos referenciados equivale a cerca de 60 mil arquivos (30 mil do FGTS, 15 mil MTE e 15 previdência), algo que tende a ser um limitante ao uso dos dados para subsidiar uma análise ou estudo.

Em relação aos dados do cadastro do MTE, observa-se um grande percentual de homonímia entre os dirigentes dos sindicatos (cerca de $22 \%$ ), algo que pode indicar a mero movimento pela formalização das entidades, visando, possivelmente, apenas, ao recebimento da contribuição sindical, sem que isso necessariamente reflita-se em representação. Na mesma linha, os dados que mostram a preocupação com a formalização, e estabelecimento de áreas de atuação, pode-se mencionar os dados de mais de 9 mil convocações via DOU entre 2005 e 2012, o que se referente a mais de metade de todos sindicatos cadastrados, algo que contrasta com a quantidade de solicitações anteriores. Já o cadastro do MTE apresenta diversos sindicatos em situação ativa, quase 6000, mas cujo último processamento indica situação diversa. Isso indica ou que a documentação é insubsistente ou que o trabalho do MTE não atende à velocidade de cadastramento que lhe seria exigida. Outra lacuna apresentada refere-se ao grande número de entidades que não declaram filiação na estrutura sindical. Tais situações cadastrais falhas ou lacunosas não se coadunam com a necessidade de estrita legalidade e cumprimento de regras nas distribuições de recursos da contribuição sindical. Mesmo

51 Os dados da Caixa ou Previdência podem em si estar errados, mas têm presunção de veracidade e são usados por terceiros. Por fim, se há uma ação ou procedimento hábil a certidão é alterada, para positiva com efeitos de negativa, se implicar em suspensão de exigibilidade, ou mesmo alterada no todo, se for mostrado erro nos dados estatais. 
que o MTE não adentre em aspectos intrínsecos do cadastro, para não atingir a autonomia do cadastro, não é crível que quaisquer dados sejam inclusos, ou não atualizados, já que são usados para respaldar a distribuição de vultuosos valores.

Frente ao número de sindicatos, no texto se menciona que existem poucas convenções e acordos coletivos em que se foi dada publicidade por meio do site do MTE, mesmo com previsão na CLT, algo que pode indicar baixa atividade dos entes, baixa taxa de sucesso, ou mero descaso com a publicidade das negociações. De qualquer forma, é crível se imaginar que num cenário em que se busque a ampliação da base de associados, a publicidade dos resultados se torne algo essencial. Outro tipo de documentação que se faz ausente são os relativos aos dados cadastrais, já que se apresenta um mero extrato de cada documento, e que poderiam subsidiar uma interpretação mais aprofundada do quadro, bem como dirimir ou identificar dúvidas sobre conflitos cadastrais. Conforme foi mencionado, tais documentos não são apresentados em forma eletrônica, o que gera uma barreira ao conhecimento do que efetivamente é pedido, aceitos e suas razões. Ademais, foi questionada a não obrigatoriedade do uso de cadastro com certificação digital, uma vez que o uso de documentos e assinaturas eletrônicas poderia contribuir decisivamente para a publicidade das informações, sua atualização e coerência, e a principal barreira ao seu uso, que é a obtenção do certificado digital, pode ser considerada fora de questão uma vez que órgãos/empresas tais como Receita Federal, Previdência Social, Caixa Econômica Federal (CEF) (no âmbito da Conectividade social) passaram a exigir o uso de certificados digitais, com prazos de adaptação já encerrados.

\section{Conclusão}

De modo geral, são apresentados dados que mostram que a maioria dos sindicatos estão operando com falhas legais e formais, assim como há diversos indícios de que buscam formalização apenas para recebimento de recursos públicos recolhidos compulsoriamente. Não se trata de dizer, por óbvio, que todos sindicatos incorram em tais enquadramentos, mas é um forte indicativo que a contribuição social compulsória não atende, em regra, os seus objetivos de garantir a sustentabilidade de entidades de representação dos trabalhadores. As discussões acerca do fim da contribuição social sempre consideram que existem sindicatos que podem não sobreviver sem esse recurso financeiro, mas tal preocupação só subsiste para o caso das entidades que representam efetivamente os trabalhadores vinculados. Os dados mostram que possivelmente a maior parte das entidades só existem para receber recursos - embora certamente não faltem quem advogue contra às evidências formais apresentadas neste texto - , e estas realmente correriam riscos de não sobreviver com o eventual fim das contribuições compulsórias, mas isso não envolve a preocupação com a legitimação da atividade sindical.

Com tais argumentos, o texto propicia a defesa do fim da contribuição sindical obrigatória nos moldes como tem sido executada nas últimas décadas, dando provas do desvio de finalidade que tal contribuição tem significado. Desse modo surgiria espaço para uma melhor equalização entre territorialidade, representação e unicidade. Também não se pode esquecer que o papel estatal, mesmo que seja no controle cadastral, está aquém daquilo que se poderia esperar de mínimo de eficiência e publicidade, e tem se tornado uma porta para fraudes. Tal situação justifica uma transparência efetiva de informações, como também a revisão dos processos interno do Ministério do Trabalho e Emprego. Outro direcionamento proposto é o reconhecimento de que tal atuação está em descordo com os princípios constitucionais que regem a atuação da administração pública, não havendo espaço para que continue do modo como apresentado.

Por fim, destaca-se que a não ingerência estatal nos sindicatos não equivale ou implica ao não controle sobre o cadastro sindical e comprovações de gastos da contribuição sindical ou de repasses públicos em algum grau. É contraditório que na defesa da liberdade sindical e representatividade se defenda um mecanismo essencialmente compulsório e que tem sido base de muitas amarras ao exercício da liberdade de 
negociação amparada por sindicatos fortes e representativos. Na forma como o sistema está, trata-se de uma conta de chegada, em que se criam mecanismo para a justificação de distorções de longa data, e, com isso, se emperra o processo de mudança e adequação da atividade sindical pautado nos interesses daqueles que deveriam ser seus efetivos beneficiários: os trabalhadores.

\section{REFERÊNCIAS}

ANDRADE, Alexsander Fernandes. Os desafios para a liberdade sindical plena. Jornal trabalbista Consulex, Brasília, v. 28, n. 1385, p. 7, jul. 2011.

AROUCA, José Carlos. A liberdade sindical e a imposição da cobrança de contribuição. Repertório IOB de jurisprudência: trabalhista e previdenciário, São Paulo, n. 2, p. 73-69, jan. 2012.

CASTRO, Ismênia E. Oliveira de; FARANI, Veruska. Dos conflitos legais decorrentes da coexistência de idênticos sindicatos de categoria. Repertório IOB de jurisprudência: trabalhista e previdenciário, São Paulo, n. 7, p. 215-211, abr. 2011.

FIORAVANTE, Tamira Maira; ALOUCHE, Luiz Fernando. Fontes de custeio dos sindicatos no Brasil: panorama geral. Jornal trabalhista Consulex, Brasilia, v. 28, n. 1366, p. 4-5, mar. 2011.

MEIRELLES, Davi Furtado. Liberdade sindical: o modelo ideal. Revista de direito do trabalho, São Paulo, v. 36, n. 137, p. 45-75, jan./mar. 2010.

MORALES, Cláudio Rodrigues. Enquadramento sindical após a Constituição de 1988. São Paulo: LTr, 2003.

MOURÃO, Alysson Sousa. A constitucionalidade da destinação da contribuição sindical às centrais sindicais. Revista tributária e de finanças públicas, São Paulo, v. 19, n. 101, p. 125-139, nov./dez. 2011.

REIS, Daniela Muradas. A imposição da contribuição sindical e o princípio da liberdade associativa: reflexões sobre o regime democrático e o financiamento sindical brasileiro. Repertório IOB de jurisprudência: trabalhista e previdenciário, São Paulo, n. 5, p. 158-150, mar. 2012.

ZAPATA, Sandor Ramiro Darn. A crise do paradigma sindical brasileiro: unicidade, contribuição obrigatória, sistema confederativo e poder normativo da justiça do trabalho. Revista de direito do trabalho, São Paulo, v. 37, n. 142, p. 387-419, abr./jun. 2011. 
Para publicar na revista Brasileira de Políticas Públicas, acesse o endereço eletrônico www.rbpp.uniceub.br

Observe as normas de publicação, para facilitar e agilizar o trabalho de edição. 